\title{
Pyrazolo Derivatives as Potent Adenosine Receptor Antagonists: An Overview on the Structure-Activity Relationships
}

\author{
Siew Lee Cheong, ${ }^{1}$ Gopalakrishnan Venkatesan, ${ }^{1}$ Priyankar Paira, ${ }^{1}$ \\ Ramasamy Jothibasu, ${ }^{1}$ Alexander Laurence Mandel, ${ }^{1}$ Stephanie Federico, ${ }^{2}$ \\ Giampiero Spalluto, ${ }^{2}$ and Giorgia Pastorin ${ }^{1}$ \\ ${ }^{1}$ Department of Pharmacy, National University of Singapore, 3 Science Drive 2, Singapore 117543 \\ ${ }^{2}$ Dipartimento di Scienze Farmaceutiche, Università degli Studi di Trieste, Piazzale Europa 1, 34127 Trieste, Italy \\ Correspondence should be addressed to Giorgia Pastorin, phapg@nus.edu.sg
}

Received 2 November 2010; Accepted 10 February 2011

Academic Editor: Rosaria Volpini

Copyright () 2011 Siew Lee Cheong et al. This is an open access article distributed under the Creative Commons Attribution License, which permits unrestricted use, distribution, and reproduction in any medium, provided the original work is properly cited.

In the past few decades, medicinal chemistry research towards potent and selective antagonists of human adenosine receptors (namely, $\mathrm{A}_{1}, \mathrm{~A}_{2 \mathrm{~A}}, \mathrm{~A}_{2 \mathrm{~B}}$, and $\mathrm{A}_{3}$ ) has been evolving rapidly. These antagonists are deemed therapeutically beneficial in several pathological conditions including neurological and renal disorders, cancer, inflammation, and glaucoma. Up to this point, many classes of compounds have been successfully synthesized and identified as potent human adenosine receptor antagonists. In this paper, an overview of the structure-activity relationship (SAR) profiles of promising nonxanthine pyrazolo derivatives is reported and discussed. We have emphasized the SAR for some representative structures such as pyrazolo-[4,3-e]-1,2,4triazolo-[1,5-c]pyrimidines; pyrazolo-[3,4-c] or -[4,3-c] quinolines; pyrazolo-[4,3- $d]$ pyrimidinones; pyrazolo-[3,4- $d]$ pyrimidines and pyrazolo-[1,5-a]pyridines. This overview not only clarifies the structural requirements deemed essential for affinity towards individual adenosine receptor subtypes, but it also sheds light on the rational design and optimization of existing structural templates to allow us to conceive new, more potent adenosine receptor antagonists.

\section{Introduction}

Adenosine is an endogenous nucleoside that mediates a wide range of physiological responses through interaction with specific adenosine receptors (ARs), which are G-proteincoupled receptors (GPCRs) comprising the characteristic seven transmembrane domains connected by three extracellular and three intracellular loops. There are four basic types of ARs that have been cloned and pharmacologically characterized, namely, $A_{1}, A_{2 A}, A_{2 B}$, and $A_{3}$ ARs [1]. Each of these ARs is associated with its own distinct biochemical pathways. Typically, the activation of $A_{1}$ and $A_{3}$ receptors mediates adenylyl cyclase inhibition through an interaction with $\mathrm{G}_{i}$ protein, followed by a subsequent decrease in the level of cyclic adenosine monophosphate (cAMP); conversely, the $\mathrm{A}_{2 \mathrm{~A}}$ and $\mathrm{A}_{2 \mathrm{~B}}$ receptors stimulate the adenylyl cyclase activity via the $\mathrm{G}_{s}$ protein thereby increasing the level of cAMP [2]. In addition, other signaling pathways involving phospholipases $\mathrm{C}$ and $\mathrm{D}$, and $\mathrm{Ca}^{2+}$ and mitogen-activated protein kinases (MAPK) have also been described [1]. Pharmacologically, the inhibition of $A_{1}$ receptors has led to implications in the renal system disorders through regulation of diuresis and neurological disorders such as Alzheimer's disease $[3,4]$; on the other hand, $A_{3}$ receptor antagonists are primarily related to the treatment of glaucoma, renal protection, inflammatory disorders like asthma, as well as cancer [57]. Studies have also found that $A_{2 A}$ receptor antagonists can reverse Parkinsonian motor deficits in preclinical models of Parkinson's disease, and they do so without inducing or exacerbating dyskinesias in nonhuman primate models $[8$, 9]. As for the $A_{2 B}$ receptor, its antagonists seem to be suitable for the treatment of certain forms of inflammatory processes such as asthma via modulation of mast cell degranulation $[10,11]$. 
In the last 15 years, intensive efforts in medicinal chemistry to design and synthesize new AR antagonists have led to the discovery of potent and selective ligands (with either agonistic or antagonistic properties) for the $A_{1}, A_{2 A}$, $A_{2 B}$, and $A_{3}$ ARs. These new derivatives have resulted in a better understanding of the pathophysiological role of these receptors; more precisely, among the AR antagonists, several different types of xanthine-derived and nonxanthine-based polyheterocyclic structures have been identified as potent AR antagonists. Some of them are shown to possess good affinity exclusively towards a particular AR subtype with concomitant improvements in their selectivity profiles. On the other hand, some scaffolds demonstrate good binding affinity across more than one AR subtype, with relatively lower selectivity profile. Among these diverse classes of compounds, nonxanthine pyrazolo derivatives have been reported to show good potency towards ARs, together with a broad range of selectivity. The aim of this review is to briefly summarize the structure-activity relationship profiles of various nonxanthine derivatives containing the pyrazole moiety as $\mathrm{AR}$ antagonists to the $\mathrm{A}_{1}, \mathrm{~A}_{2 \mathrm{~A}}, \mathrm{~A}_{2 \mathrm{~B}}$, and $\mathrm{A}_{3}$ receptor subtypes.

\section{Pyrazolo Derivatives as Potent AR Antagonists}

In general, nonxanthine AR antagonists are represented by polyheterocyclic derivatives which are categorized as monocyclic, bicyclic, or tricyclic structures [12]. In this review, we emphasized the structure-activity relationships for some of the representative nonxanthine pyrazolo derivatives (i.e., derivatives with a fused pyrazole ring in their respective core nuclei), which have been identified as potent AR antagonists at the $A_{1}, A_{2 A}, A_{2 B}$, or $A_{3}$ receptor subtypes. These derivatives are pyrazolo-[4,3-e]1,2,4-triazolo-[1,5-c]pyrimidines, pyrazolo- $[3,4-c]$ or - $[4,3-c]$ quinolines, pyrazolo-[4,3d]pyrimidinones, pyrazolo-[3,4-d]pyrimidines, and pyrazolo-[1,5-a]pyridines. The binding data of the most representative $\mathrm{AR}$ antagonists belonging to these series are reported in Table 1.

\subsection{Pyrazolo-[4,3-e]-1,2,4-triazolo-[1,5-c]pyrimidine}

2.1.1. $A_{2 A}$ AR Antagonists. The pyrazolo-triazolo-pyrimidine derivatives were first described as AR antagonists by Gatta and coworkers [13], who identified a compound named 8FBPTP ( 1 in Figure 1), which demonstrated good binding to the $A_{2 A} A R$ but lacked selectivity towards the $A_{1}$ receptor subtype. Structure-affinity relationship studies showed that the free amino group at 5-position and the effect of the substituents on the pyrazole ring seemed important for both high affinity and selectivity for the $\mathrm{A}_{2 \mathrm{~A}} \mathrm{AR}$ subtype. From further studies, substitutions at the 7-position were shown to improve the selectivity for the $A_{2 A}$ receptor while the same substitutions at the 8-position increased affinity to the $A_{1}$ and $A_{2 A}$ receptors with low levels of selectivity, as indicated by the $\mathrm{N}^{7}-n$-butyl (2) and the $\mathrm{N}^{8}-n$-butyl (3) derivatives $[14,15]$. This again indicated that the presence of a chain (preferably a long (ar)alkyl one) at the $\mathrm{N}^{7}$ position seemed essential for both affinity and selectivity for the $A_{2 A}$ receptors.

In fact, two selected compounds named SCH 63390 (4) and SCH 58261 (5) proved to be the most potent and selective $A_{2 A} A R$ antagonists ever reported, both in rat and human models [15-17]. The latter was further developed into an $\mathrm{A}_{2 \mathrm{~A}}$ antagonist radioligand, $\left[{ }^{3} \mathrm{H}\right] \mathrm{SCH} 58261$ (5a) with a $K_{D}$ value of about $1 \mathrm{nM}$. Further studies have suggested that it could be a useful tool for characterization of $\mathrm{A}_{2 \mathrm{~A}}$ receptor subtypes in platelets, autoradiography assays, and labeling of striatal $A_{2 A}$ receptors for studying $A_{2 A}$ receptor occupancy of various antagonists $[18,50,51]$. Nevertheless, this class of compounds presents a significant problem because of poor water solubility. To overcome this drawback, several polar moieties on the side chain of the pyrazole nucleus have been introduced. In particular, the introduction of a hydroxyl function at the para position of the phenyl ring of compounds (4) and (5) led to derivatives (5-amino-7-[3(4-hydroxyphenyl)propyl]-2-(2-furyl)pyrazolo[4,3-e]1,2,4triazolo[1,5-c]pyrimidine) (6) and (5-amino-7-[ $\beta$ - $(4-$ hydroxyphenyl)ethyl]-2-(2-furyl)pyrazolo[4,3-e]1,2,4-triazolo[1,5-c]pyrimidine) (7), which not only showed a better hydrophilic character but also a significant increase of both affinity and selectivity for the $\mathrm{A}_{2 \mathrm{~A}}$ AR subtype, suggesting that most probably, a hydrogen bond is involved in receptor recognition via this part of the ligand [16].

To understand the nature of such a hypothetical hydrogen bond, compound SCH 442416 (8) was synthesized. This derivative showed even higher affinity and selectivity for the $A_{2 A}$ receptor, thus representing a suitable candidate for positron emission tomography (PET) studies in its ${ }^{11} \mathrm{C}$ labeled form [19]. Moreover, it was developed into novel fluorescent tracer MRS5346 (9), which was conjugated to the fluorescent dye Alexa Fluor-488. It has a $K_{D}$ value of 16.5 $\pm 4.7 \mathrm{nM}$ and could be used in fluorescence polarization competition binding experiments as well as high-throughput screening [20]. On top of that, this SCH 442416 derivative also confirmed the role of a hydrogen bond via the pyrazolo side chain. Nonetheless, the introduction of oxygenated groups could not be considered sufficient to confer water solubility. Hence, carboxylic (10) and sulfonic (11) moieties were introduced, and such structural modifications (the sulfonic moiety in particular) improved water solubility. However, in some cases, a loss of affinity with respect to reference compounds $(6,7)$ for the $A_{2 A} A R$ was observed. On the other hand, the introduction of an amino group at the para position of the phenyl ring (12) improved both affinity and selectivity towards the $\mathrm{A}_{2 \mathrm{~A}}$ receptor, although with low water solubility [17]. Despite these observations, it was found that the $\mathrm{N}^{7}$ derivative (such as compound 5) was totally inactive to the human $\mathrm{A}_{2 \mathrm{~B}}$ and $\mathrm{A}_{3}$ receptors. The $\mathrm{N}^{8}$ regioisomer (13), however, showed a slight affinity profile for these two receptor subtypes $[21,22]$.

A recent series of pyrazolo-triazolo-pyrimidine derivatives was obtained by modifying the phenylethyl substituent of $\mathbf{5}$ with substituted phenylpiperazine ethyl groups [23]. Introduction of fluorine atoms in the phenyl ring (14) enhanced the affinity to subnanomolar values and 
TABLE 1: Binding affinities of pyrazolo derivatives at $A_{1}, A_{2 A}, A_{2 B}$, and $A_{3}$ ARs.

\begin{tabular}{|c|c|c|c|c|c|c|}
\hline & & & Pyrazolo deriv & & & \\
\hline Type of & Compounds & & $K_{i}$, a & 1) or $\%$ of $i$ & & \\
\hline & & $\mathrm{A}_{1}{ }^{\mathrm{a}}$ & $\mathrm{A}_{2 \mathrm{~A}}^{\mathrm{b}}$ & $\mathrm{A}_{2 \mathrm{~B}} \mathrm{c}$ & $\mathrm{A}_{3}{ }^{\mathrm{d}}$ & Refs. \\
\hline & & & zzolo-[4,3-e] tria & c]pyrimidir & & \\
\hline & & & $A_{2 A} A R$ & & & \\
\hline & $\mathbf{1}, 8$ FB-PTP & $3.3^{\mathrm{e}}$ & $1.2^{\mathrm{f}}$ & ND & ND & [13] \\
\hline & 2 & $236^{\mathrm{e}}$ & $8.9^{f}$ & ND & ND & {$[14,15]$} \\
\hline & 3 & $30.4^{\mathrm{e}}$ & $2.4^{\mathrm{f}}$ & ND & ND & {$[14,15]$} \\
\hline & 4, SCH 63390 & $504^{e}$ & $2.4^{\mathrm{f}}$ & ND & $>10,000$ & {$[15-17]$} \\
\hline & 5, SCH 58261 & $121^{\mathrm{e}}$ & $2.3^{\mathrm{f}}$ & ND & $>10,000$ & {$[15-17]$} \\
\hline & 5a, $\left[{ }^{3} \mathrm{H}\right] \mathrm{SCH} 58261$ & - & $K_{D}=1 \mathrm{nM}$ & - & - & {$[18]$} \\
\hline & 6 & $741^{\mathrm{e}}$ & $0.94^{\mathrm{f}}$ & ND & $>10,000$ & {$[16]$} \\
\hline & 7 & $444^{\mathrm{e}}$ & $1.7^{\mathrm{f}}$ & ND & $>10,000$ & {$[16]$} \\
\hline & 8, SCH 442416 & 1,111 & 0.048 & $>10,000$ & $>10,000$ & [19] \\
\hline & 9, MRS5346 & - & $K_{D}=16.5 \mathrm{nM}$ & - & - & [20] \\
\hline & 10 & 4,927 & 4.63 & $>10,000$ & $>10,000$ & [17] \\
\hline & 11 & 190 & 100 & $>10,000$ & $>10,000$ & {$[17]$} \\
\hline & 12 & 2,160 & 0.22 & $>10,000$ & $>10,000$ & {$[17]$} \\
\hline & 13 & 1 & 0.34 & 5.1 & 280 & {$[21,22]$} \\
\hline & 14 & $>960$ & 0.6 & ND & ND & [23] \\
\hline & 15, SCH 420814 & $>1,000$ & 1.1 & $>1,700$ & $>1,000$ & [23] \\
\hline Tricyclic & & & $A_{2 B} A R$ & & & \\
\hline scaffold & 16 & 2 & 0.8 & 9 & 700 & [24] \\
\hline & 17 & 1.6 & 54 & 27 & 65 & [24] \\
\hline & 18 & 702 & 423 & 165 & 0.81 & [25] \\
\hline & 19 & 1,100 & 800 & 20 & 300 & [25] \\
\hline & & & $A_{3} A R$ & & & \\
\hline & 21 & 1,026 & 1,040 & 245 & 0.6 & {$[21]$} \\
\hline & $\begin{array}{c}\text { 22, } \\
{\left[{ }^{3} \mathrm{H}\right] \text { MRE-3008-F20 }}\end{array}$ & - & - & - & $K_{D}=0.8 \mathrm{nM}$ & [26] \\
\hline & 23 & 594 & 381 & 222 & 0.16 & {$[22,27-29]$} \\
\hline & 24 & 350 & 100 & 250 & 0.01 & {$[30]$} \\
\hline & 25 & 235 & $>1,000$ & $>1,000$ & $>1,000$ & {$[31]$} \\
\hline & 26 & 562 & 778 & $>10,000^{g}$ & 0.108 & {$[32]$} \\
\hline & 27 & $38^{\mathrm{h}}$ & $120^{\mathrm{i}}$ & $1,500^{j}$ & $4.1^{\mathrm{k}}$ & {$[6,33]$} \\
\hline & 28 & $610^{\mathrm{h}}$ & $>10,000^{\mathrm{i}}$ & $9,400^{j}$ & $1.9^{\mathrm{k}}$ & {$[6,33]$} \\
\hline & 29 & 150 & 21 & 37 & 17 & {$[31]$} \\
\hline & & & Pyrazol & & & \\
\hline & & & $A_{3} A R$ & & & \\
\hline & 30 & $32 \%$ & $21 \%^{\mathrm{m}}$ & ND & 0.6 & {$[34-38]$} \\
\hline & 31 & $45 \%$ & $24 \%$ & $>1,000$ & 1 & [37] \\
\hline & 32 & $464^{1}$ & $35 \% \%^{\mathrm{m}}$ & ND & 2.9 & {$[39,40]$} \\
\hline & 33 & 40 & 1,060 & ND & 90.2 & {$[39,40]$} \\
\hline & 34 & $0 \%$ & $9 \%$ & ND & 2.1 & {$[39,40]$} \\
\hline & 35 & $>1,000$ & $>1,000$ & $>1,000^{\mathrm{n}}$ & 9.0 & {$[41]$} \\
\hline
\end{tabular}


Table 1: Continued.

\begin{tabular}{|c|c|c|c|c|c|c|}
\hline \multicolumn{7}{|c|}{ Pyrazolo derivatives } \\
\hline \multirow{2}{*}{$\begin{array}{l}\text { Type of } \\
\text { scaffold }\end{array}$} & \multirow[t]{2}{*}{ Compounds } & \multicolumn{5}{|c|}{$K_{i}$, affinity $(\mathrm{nM})$ or $\%$ of inhibition } \\
\hline & & $\mathrm{A}_{1}{ }^{\mathrm{a}}$ & $\mathrm{A}_{2 \mathrm{~A}}{ }^{\mathrm{b}}$ & $\mathrm{A}_{2 \mathrm{~B}}^{\mathrm{c}}$ & $\mathrm{A}_{3}{ }^{\mathrm{d}}$ & Refs. \\
\hline & \multicolumn{6}{|c|}{ Pyrazolo- $[4,3-d]$ pyrimidinone } \\
\hline & \multicolumn{6}{|c|}{$A_{3} A R$ antagonist } \\
\hline & 36 & $5 \%$ & $1 \%$ & $2 \%^{\mathrm{g}}$ & 1.2 & {$[42]$} \\
\hline & \multicolumn{6}{|c|}{ Pyrazolo- $[3,4-d]$ pyrimidine } \\
\hline & \multicolumn{6}{|c|}{$A_{1} A R$ antagonists } \\
\hline & 37 & $370^{\mathrm{e}}$ & ND & ND & ND & {$[43,44]$} \\
\hline & 38 & $0.939^{\mathrm{e}}$ & $88.3^{\mathrm{f}}$ & ND & ND & {$[44]$} \\
\hline & 39 & $0.745^{\mathrm{e}}$ & $247^{\mathrm{f}}$ & ND & ND & {$[44]$} \\
\hline \multirow{12}{*}{$\begin{array}{l}\text { Bicyclic } \\
\text { scaffold }\end{array}$} & \multicolumn{6}{|c|}{$A_{2 A} A R$ antagonists } \\
\hline & 40 & 647 & 48 & ND & ND & {$[45]$} \\
\hline & 41 & 468 & 3 & ND & ND & {$[45]$} \\
\hline & 42 & 206 & 1 & ND & ND & {$[45]$} \\
\hline & \multicolumn{6}{|c|}{$A_{3} A R$ antagonists } \\
\hline & 43 & 334 & 728.1 & $49.8^{\mathrm{n}}$ & 0.60 & {$[46]$} \\
\hline & 44 & 1,037 & 3,179 & $53.9^{n}$ & 0.18 & {$[46]$} \\
\hline & \multicolumn{6}{|c|}{ Pyrazolo- $[1,5-a]$ pyridine } \\
\hline & \multicolumn{6}{|c|}{$A_{1} A R$ antagonists } \\
\hline & 45, FK453 & $17^{\circ}$ & $11,000^{\mathrm{p}}$ & ND & ND & {$[47]$} \\
\hline & 46, FK838 & $120^{\circ}$ & $5900^{p}$ & ND & ND & {$[48]$} \\
\hline & 47, FR166124 & $15^{\circ}$ & $6200^{p}$ & ND & ND & [49] \\
\hline $\begin{array}{l}\text { ND: Not d } \\
\text { a, b, c, d: bin } \\
\text { e: binding } \\
\text { f: binding } \\
\text { g: adenylyl } \\
\text { h, i, , k: } \text { IC }_{50} \\
\text { ': binding a } \\
\text { m: binding } \\
\text { n: IC } \text { I }_{50} \text { val } \\
\text { o: } \text { IC }_{50} \text { val } \\
\mathrm{p}: \mathrm{IC}_{50} \text { valı }\end{array}$ & $\begin{array}{l}\text { ined. } \\
\text { ffinity assay detern } \\
\text { y assay determined } \\
\text { y assay determined } \\
\text { e assay determinec } \\
\text { from binding affi } \\
\text { assay determined } \\
\text { ty assay determine } \\
\mathrm{m} \text { adenylyl cyclase } \\
\mathrm{m} \text { binding affinity } \\
\mathrm{m} \text { binding affinity }\end{array}$ & $\begin{array}{l}\text { g recomb } \\
\text { in rat brai } \\
\mathrm{R} \text { in rat str } \\
\text { combinant } \\
\text { determine } \\
\text { in bovine } \\
\mathrm{R} \text { in bovir } \\
\mathrm{rmined} \text { at } \\
\text { rmined at } \\
\text { rmined at }\end{array}$ & $\begin{array}{l}\text { ssing hun } \\
\text { s. } \\
\text { human A } \\
\mathrm{H}_{1} \mathrm{AR}, \mathrm{A}_{2} \\
\text { membra } \\
\text { ranes. } \\
\text { in memb }\end{array}$ & $\begin{array}{l}\mathrm{R}, \mathrm{A}_{2 \mathrm{~B}} \\
\mathrm{~d} \mathrm{~A}_{3} \mathrm{AR}\end{array}$ & ective & \\
\hline
\end{tabular}

the compounds displayed potent oral activity, but their solubilities still remained poor. Further introduction of ether substituents led to derivatives with high affinities and selectivities for $\mathrm{A}_{2 \mathrm{~A}}$ receptors and improvements in water solubility. In particular, one of these compounds (SCH 420814, Privadenant, 15) exhibited high affinity for both rat and human $\mathrm{A}_{2 \mathrm{~A}}$ receptors, with $K_{i}$ values of 2.5 and $1.1 \mathrm{nM}$, respectively. In addition, the compound was very selective for human $A_{2 A}$ receptors over $A_{1}, A_{2 B}$, and $\mathrm{A}_{3}$ receptors. Interestingly, the compound did not show significant binding against a panel of 59 unrelated receptors, enzymes and ion channels. Privadenant is now in Phase II Clinical Trials for the treatment of dyskinesia in Parkinson's disease.
2.1.2. $A_{2 B} A R$ Antagonists. The binding data obtained from parallel studies on $\mathrm{A}_{2 A}$ receptor antagonists have indicated that the $\mathrm{N}^{5}$-unsubstituted pyrazolo-triazolo-pyrimidine derivatives (13 in Figure 1, 16 in Figure 2) possessed high affinity to the human $A_{2 B}$ receptors but completely lacked selectivity. Subsequently, introduction of a polar $\gamma$ amino-butyryl amide (17) at the $\mathrm{N}^{5}$-position decreased affinity towards the $A_{2 B}$ receptors but was found to be slightly selective against the $A_{2 A}$ subtype [24]. An improvement of this class of compounds was further achieved by an optimized pattern of substitutions at the $\mathrm{N}^{5}$ - and $\mathrm{N}^{8}$ positions. In fact, in parallel studies on human $A_{3}$ receptor antagonists (to be elaborated in the following section), it was observed that replacement of the phenylcarbamoyl moiety 


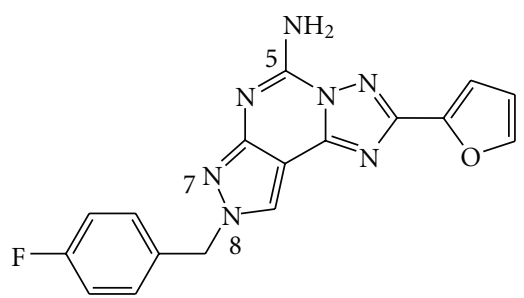

1<smiles>CCCCn1cc2c(nc(N)n3nc(-c4ccco4)nc23)n1</smiles>

3<smiles>CCCCn1ncc2c1nc(N)n1nc(-c3ccco3)nc21</smiles>

2<smiles>Nc1nc2c(cnn2CCCc2ccccc2)c2nc(-c3ccco3)nn12</smiles>

4<smiles>Nc1nc2c(cnn2CCCc2ccc(O)cc2)c2nc(-c3ccco3)nn12</smiles>

5

$5 a$

6<smiles>Nc1nc2c(cnn2CCc2ccc(O)cc2)c2nc(-c3ccco3)nn12</smiles><smiles>COc1ccc(CCCn2ncc3c2nc(N)n2nc(-c4ccco4)nc32)cc1</smiles>

7

8

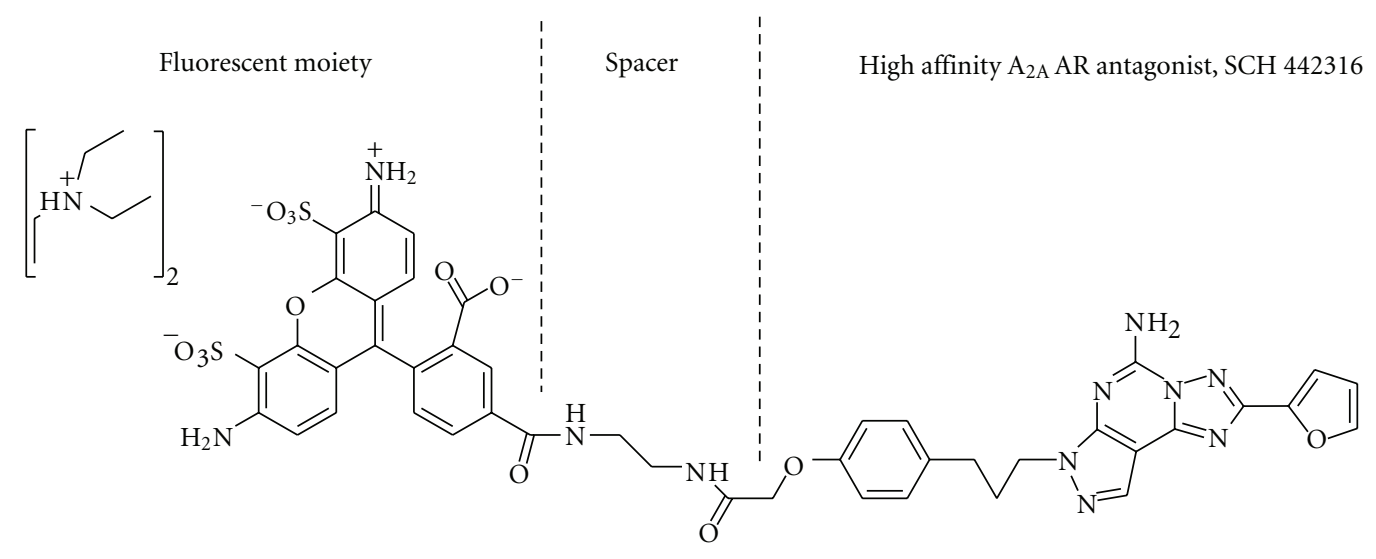

9

(a)

FIgURE 1: Continued. 

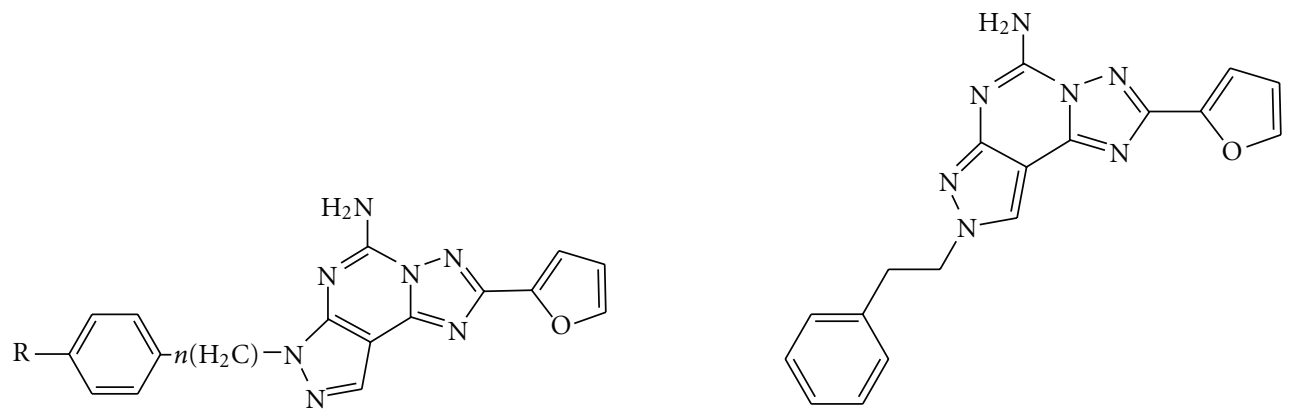

$$
\begin{aligned}
& 10, n=3 ; \mathrm{R}=\mathrm{COOH} \\
& 11, n=2 ; \mathrm{R}=\mathrm{SO}_{3} \mathrm{H} \\
& 12, n=3 ; \mathrm{R}=\mathrm{NH}_{2}
\end{aligned}
$$

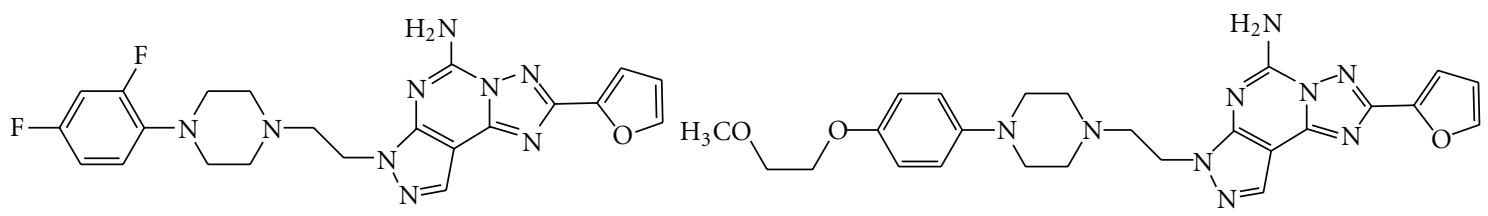

14

15

(b)

FIGURE 1: Structures of pyrazolo-triazolo-pyrimidines as $A_{2 \mathrm{~A}} \mathrm{AR}$ antagonists.

at the $\mathrm{N}^{5}$-position with a phenylacetyl group (compound 18) produced a decrease in affinity to the human $A_{3} A R$ and a retention or improvement towards the $\mathrm{A}_{2 \mathrm{~B}}$ subtype. A combination of a naphthyl acetyl moiety at the $\mathrm{N}^{5}$-position and a phenyl propyl group (characteristic of $\mathrm{A}_{2 \mathrm{~A}}$ antagonists) at the $\mathrm{N}^{8}$ position led to a compound (19), which was found to be quite potent and selective towards the $A_{2 B}$ ARs [25]. These findings indicated that bulky substituents at both the $\mathrm{N}^{5}$ - and $\mathrm{N}^{8}$-positions could lead to potent and selective $A_{2 B} A R$ antagonists, thus suggesting the presence of a larger pocket in the receptor binding site.

2.1.3. $A_{3} A R$ Antagonists. The optimization approach to obtain potent $\mathrm{A}_{3} \mathrm{AR}$ antagonists in the series of pyrazolotriazolo-pyrimidines was a hybrid molecule between a human $A_{2 A}$ receptor antagonist $[15,16]$ and an agonist of the $A_{3}$ subtype $[52,53]$. The tricyclic scaffold of a known human $\mathrm{A}_{2 \mathrm{~A}}$ antagonist was substituted at the $\mathrm{N}^{5}$ position with an aryl carbamoyl moiety. Specifically, this para-methoxyphenyl was demonstrated to be optimal for $\mathrm{A}_{3}$ affinity when introduced at the $\mathrm{N}^{6}$-position of the $\mathrm{A}_{3}$ agonist NECA (as represented by compound 20; Figure 3). Such rational design led to compound 21 , which is one of the most potent and selective human $\mathrm{A}_{3} \mathrm{AR}$ antagonists
[21]. Subsequent collation of binding data and molecular modeling studies indicated that small substituents, such as a methyl group at the $\mathrm{N}^{8}$-position, the phenyl ring on the $\mathrm{N}^{5}$-carbamoyl moiety, and a furyl ring at 2-position, were important (although not crucial, as indicated in the following paragraphs) for $\mathrm{A}_{3}$ affinity (e.g., compound 23) [22, 27-29]. Only small substituents at the para position of the phenyl ring, including fluoro $(\mathrm{F})$, chloro $(\mathrm{Cl})$, and methoxy $\left(\mathrm{OCH}_{3}\right)$ were tolerated. At the meta-position, only hydrogen was tolerated, while the ortho-position could be substituted by a chlorine atom. Introduction of an allyl chain at $\mathrm{N}^{8}$-position, followed by reduction with tritium afforded $\left[{ }^{3} \mathrm{H}\right]$ MRE-3008-F20 (22), which was the first selective and tritiated human $\mathrm{A}_{3}$ receptor antagonist radioligand [26]. It showed a $K_{D}$ value of $0.8 \mathrm{nM}$ and exhibited ca. $25 \%$ of nonspecific binding at that concentration. Since its discovery, it has been used for the identification of $A_{3}$ receptors on various cells, including Jurkat T cells, HL60 cells, and human neutrophils $[54,55]$. Later, the $\mathrm{N}^{5}$-phenyl ring of the tricyclic scaffold was substituted with a pyridinium salt, as represented by compound $\mathbf{2 4}$, which not only showed good solubility $(15 \mathrm{mM})$ but also significantly improved $\mathrm{hA}_{3}$ affinity [30]. In previous studies, substitution of the $\mathrm{N}^{5}$ pyridine moiety with various $\mathrm{N}^{5}$-heteroaryl rings resulted in a general loss of $\mathrm{hA}_{3}$ affinity and selectivity [28]. 


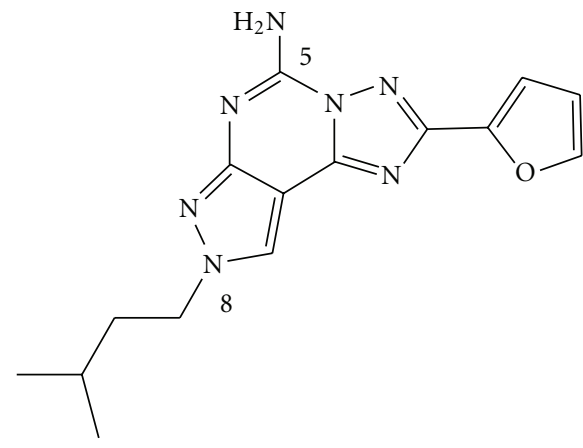

16<smiles>Cn1cc2c(nc(NC(=O)Cc3ccccc3)n3nc(-c4ccco4)nc23)n1</smiles>

18

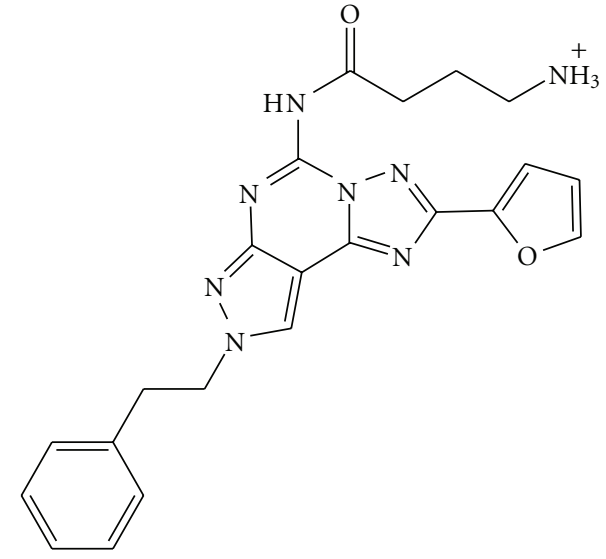

17

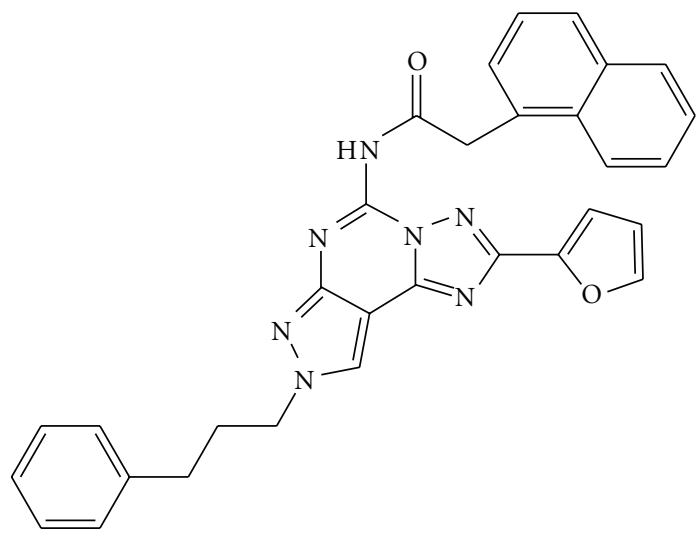

19

Figure 2: Structures of pyrazolo-triazolo-pyrimidines as $A_{2 B}$ AR antagonists.

Substitution at position $\mathrm{C}^{2}$ of the tricyclic system has not been deeply explored, being essentially limited to a furyl group. The furan ring had been considered to be an essential structural requirement for the binding of antagonists to all of the AR subtypes, since its removal from the tricyclic system was associated with an irreversible loss of affinity and selectivity, regardless of the receptor under investigation. In fact, Baraldi and coworkers [31] found that the substitution of the furan ring in PTPs with phenyl (25) or alkoxyphenyl rings led to a loss of affinity to $A_{2 A}, A_{2 B}$, and $A_{3}$ receptors, while the $A_{1}$ subtype in some cases displayed a high nanomolar binding profile. Similarly, the functionalization of the furan ring with polar substituents led to completely inactive derivatives, clearly indicating that an unsubstituted furan ring at the $\mathrm{C}^{2}$ position played a fundamental role in ligand-receptor recognition [31]. Notably, in most cases, substitution at the pyrazole ring occurred at the $\mathrm{N}^{7}$-rather than at the $\mathrm{N}^{8}$-position. Recently, a new series of 2-aryl pyrazolo-triazolo-pyrimidines was reported by Cheong et al., in which the previously conserved furan at $\mathrm{C}^{2}$ was substi- tuted with a 2-aryl ring while substitutions on pyrazole ring were maintained at the $\mathrm{N}^{8}$-position [32]. Such bioisosteric replacement at $\mathrm{C}^{2}$ resulted in improved human $\mathrm{A}_{3}$ affinity and remarkably enhanced selectivity over other AR subtypes. The para substituents at the 2-phenyl ring were generally well tolerated, except for a para-nitro group, which caused detrimental effects on $\mathrm{hA}_{3}$ affinity. Particularly, the para$\mathrm{OCH}_{3}$ and para-F groups conferred better affinities and selectivities towards the $\mathrm{hA}_{3}$ receptor. The most potent compound in this series (26) had a methyl group at the $\mathrm{N}^{8}$ position, a phenylacetamide at the $\mathrm{N}^{5}$-position, and a phenyl ring at the $\mathrm{C}^{2}$-position. Interestingly, Okamura et al. also described a series of pyrazolo-triazolo-pyrimidine analogues with a para-(un)substituted-phenyl ring and an alkyl chain at the $\mathrm{C}^{2}$ - and $\mathrm{C}^{5}$-positions, respectively, that was shown to possess good $\mathrm{hA}_{3}$ affinity. The selectivity against other AR subtypes was significantly improved in this group of derivatives, especially when a para-substituted-2-phenyl ring was present (as illustrated by compounds 27,28 ) $[6,33]$. It was also observed that the introduction of a substituent 


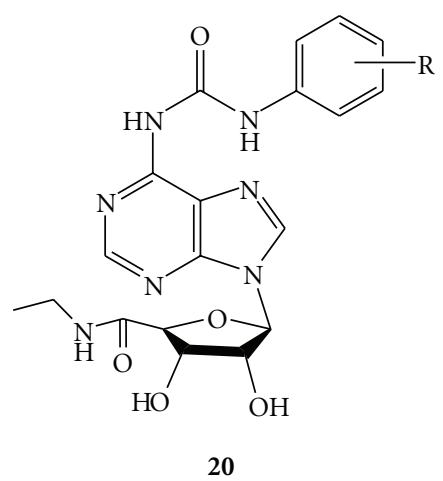<smiles>CCn1cc2c(nc(NC(=O)Nc3ccc(OC)cc3)n3nc(-c4ccco4)nc23)n1</smiles>

21<smiles>Cn1cc2c(nc(NC(=O)Nc3cc[nH+]cc3)n3nc(-c4ccco4)nc23)n1</smiles>

24<smiles>CCCc1nc2[nH]ncc2c2nc(-c3ccccc3)nn12</smiles><smiles>CCCCc1nc2[nH]ncc2c2nc(-c3ccc(F)cc3)nn12</smiles>

22

25

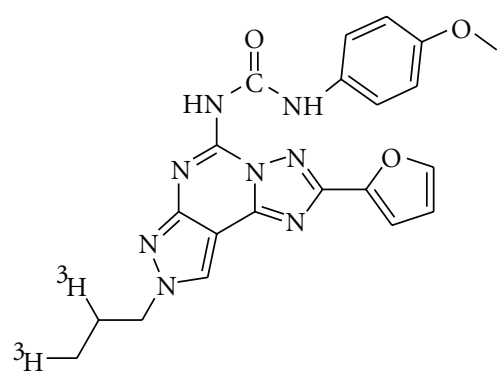<smiles>Nc1nc2c(cnn2CCc2ccccc2)c2nc(-c3ccccc3)nn12</smiles><smiles>CCNc1c2c(nc(NC(=O)Nc3ccc(OC)cc3)n3nc(-c4ccco4)nc23)nn1C</smiles><smiles>Cn1cc2c(nc(NC(=O)Nc3ccccc3)n3nc(-c4ccco4)nc23)n1</smiles>

23 
<smiles>COc1ccc(-n2nc3c(NC(=O)c4ccccc4)nc4c(N)cccc4n3c2=O)cc1</smiles>

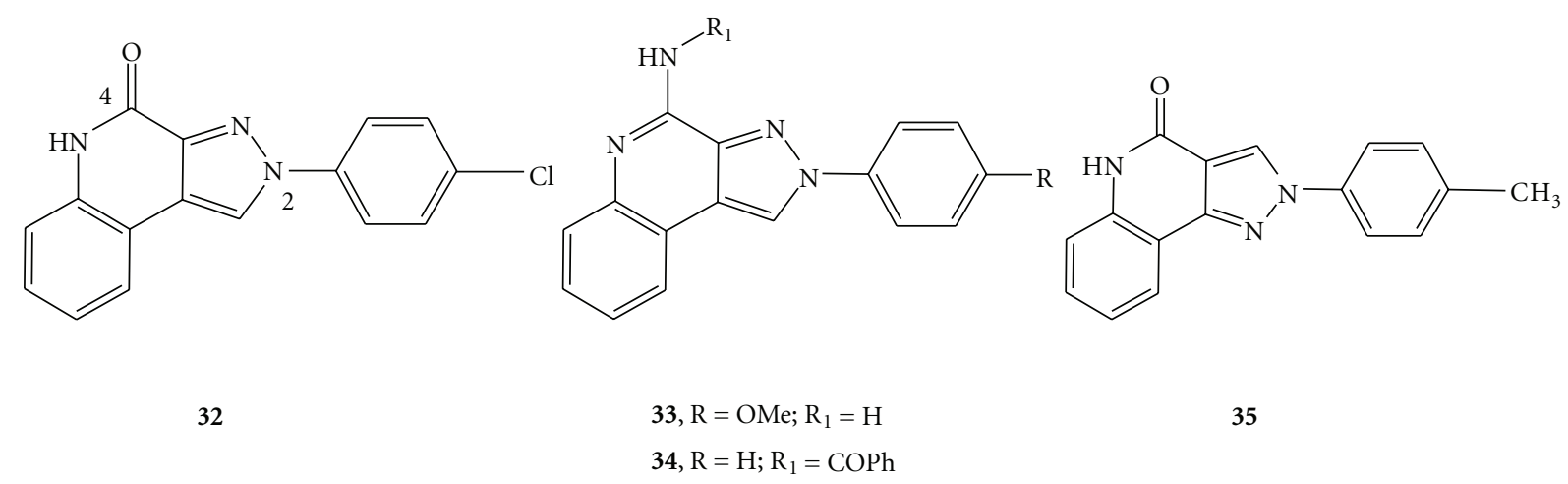

FIgURE 4: Structures of pyrazoloquinolines as $\mathrm{A}_{3} \mathrm{AR}$ antagonists.

(e.g., $\mathrm{NHCH}_{2} \mathrm{CH}_{3}$ (29) and $\mathrm{SCH}_{3}$ ) at the $\mathrm{C}^{9}$-position, induced a loss of both affinity and selectivity towards the $\mathrm{A}_{3}$ receptor. It was postulated that the introduction of these substituents caused a repulsive effect due to steric hindrance, which hampered the interaction with the binding site of the $\mathrm{A}_{3} \mathrm{AR}[31]$.

\subsection{Pyrazolo- $[3,4-c]$ or $-[4,3-c]$ quinolines}

2.2.1. $A_{3} A R$ Antagonists. The series of pyrazoloquinolin4-ones and pyrazolo[3,4-c] quinolines, 4-oxo and 4-amino substituted, shared a similar central scaffold as that of the triazoloquinoxalinones $(30,31)$ [34-38], and they were found to be potent and selective $\mathrm{A}_{3} \mathrm{AR}$ antagonists (Figure 4) $[39,40]$. The substituent on the appended 2-phenyl ring was crucial to modulate $\mathrm{A}_{3}$ affinity while a nuclear (e.g., oxo group) or extranuclear (e.g., amide group) $\mathrm{C}=\mathrm{O}$ proton acceptor at the 4-position gave rise to potent and selective $\mathrm{A}_{3}$ antagonists. At the 2-position, the presence of 4-Cl, 4$\mathrm{OCH}_{3}, 4-\mathrm{CH}_{3}$, and $3-\mathrm{CH}_{3}$ on the 2-phenyl ring resulted in enhancement of $\mathrm{A}_{3}$ affinities in both the 4-ones (32) and 4-amino (33) series. Conversely, the substituents on the 2-phenyl ring of the 4-amido derivatives generally maintained but did not ameliorate the high $\mathrm{A}_{3}$ affinities in comparison with the 2-phenyl parent derivatives. At the 4-position, the introduction of 4-benzoylamido (34), 4-phenylacetylamido, and 4-carbamoyl residues resulted in improved human $\mathrm{A}_{3}$ affinities and selectivities, confirming the importance of the $\mathrm{C}=\mathrm{O}$ group at this position towards $\mathrm{A}_{3}$ receptor-ligand interaction. Among the 4-amido derivatives, the 4-acetylamido group showed lower human $\mathrm{A}_{3}$ affinity in comparison to the other bulkier 4-acyl moieties, thus implying not only the presence of a roomy receptor pocket around this region, but also the importance of hydrophobic interactions between the 4-substituents and the receptor site. Another series of 2-phenyl-2,5-dihydro-pyrazolo[4,3c] quinolin-4-ones, which are the structural isomers of the parent 2-arylpyrazolo[3,4-c] quinoline derivatives, have also been reported by Baraldi et al. [41]. Some of the synthesized compounds showed good $\mathrm{A}_{3}$ affinities (nanomolar ranges) and excellent selectivities. Particularly, the substitution of methyl, methoxy, or chlorine at the para-position of the 2phenyl ring, together with the presence of a 4-oxo functionality gave good $\mathrm{A}_{3}$ affinity and selectivity (35).

\subsection{Pyrazolo- $[4,3-d]$ pyrimidinones}

2.3.1. $A_{3}$ AR Antagonists. The pyrazolo-[4,3-d]pyrimidin-7ones, which were a molecular simplification of the tricyclic scaffold of pyrazolo-[3,4-c] quinolin-4-one, have recently been shown to possess good affinity and selectivity profiles for the $\mathrm{hA}_{3}$ receptor [42]. According to the structure-activity 


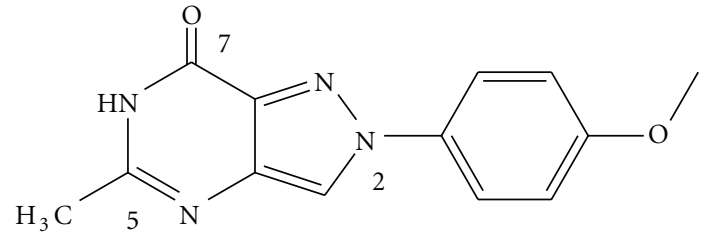

36

Figure 5: Structure of pyrazolo- $[4,3-d]$ pyrimidinone as an $\mathrm{A}_{3} \mathrm{AR}$ antagonist.

relationship (SAR) analysis, both the substituents at the $\mathrm{C}^{5}$ and $\mathrm{N}^{2}$-positions of the bicyclic nucleus were crucial for the human $\mathrm{A}_{3}$ affinity and selectivity. The concomitant presence of small alkyl chains, such as methyl group at the $\mathrm{C}^{5}$ position and a para-methoxy-substituted phenyl ring at the $\mathrm{N}^{2}$ position (as demonstrated by compound 36 in Figure 5) gave rise to the most potent and selective $\mathrm{A}_{3} \mathrm{AR}$ antagonist in this series of derivatives.

\subsection{Pyrazolo- $[3,4-d]$ pyrimidines}

2.4.1. $A_{1}$ AR Antagonists. A series of pyrazolo- $[3,4-d]$ pyrimidines was identified that contains novel $A_{1} A R$ antagonists [43]. The lead compound, 4,6-Bis $[\alpha$-carbamoylethyl)thio]1-phenylpyrazolo- $[3,4-d]$ pyrimidine (37 in Figure 6), served as a starting template for the optimization of $A_{1}$ affinity and selectivity in this series of compounds. 1-phenyl-pyrazolo- $[3,4-d]$ pyrimidine was modified at $\mathrm{C}^{4}$ with mercapto, methylthio, and amino groups in order to investigate the hydrogen-bonding and steric tolerance at this position [44]. At $\mathrm{C}^{6}$, thioesters containing distal amides with varying lengths of linear and branched alkyl groups extending from the $\alpha$-carbon were evaluated for steric and hydrophobic tolerance [44]. From the binding data at $A_{1}$ receptor, it was found that the simultaneous presence of an amino at $\mathrm{C}^{4}$ and $\alpha$-butyl side chain at $\mathrm{C}^{6}$ gave rise to the most potent compound of the series (38); the least potent compound contained a mercapto and an $\alpha$-isopropyl side chain at $\mathrm{C}^{4}$ and $\mathrm{C}^{6}$, respectively. These observations suggested that the superiority of the $\mathrm{C}^{4}$-amino group was most likely due to a hydrogen-bonding interaction with the receptor binding sites. Although a $\mathrm{C}^{4}$-methylthio group was less preferable than the amino species, its presence was still tolerable, thus indicating the existence of a hydrophobic pocket in the $A_{1}$ binding site able to accommodate the methyl group. As for the $\mathrm{C}^{6}$ position, the increase in length of the linear carbon side chain (from ethyl to butyl) was favorably tolerated at the $A_{1}$ receptor for each $\mathrm{C}^{4}$-substituent. Similarly, the hydrophobic tolerance at $\mathrm{C}^{6}$ position seemed crucial for the $\mathrm{A}_{1}$ binding affinity as well. In an attempt to test for the hypothesis mentioned above, a methyl-amino and an $\alpha$-butyl side chain were concurrently introduced at the $\mathrm{C}^{4}$ and $\mathrm{C}^{6}$ positions, respectively [44]. Accordingly, the derivative $\mathbf{3 9}$ displayed improved $\mathrm{A}_{1}$ affinity and increased $A_{1}$ selectivity, which further supported the proposed structural requirements at both the $\mathrm{C}^{4}$ and $\mathrm{C}^{6}$ positions.

2.4.2. $A_{2 A}$ AR Antagonists. Pyrazolo-[3,4-d]pyrimidines were also explored by Gillespie and collaborators as $A_{2 \mathrm{~A}} \mathrm{AR}$ antagonists [45]. In particular, the 4-(furan-2-yl)pyrazolo$[3,4-d]$ pyrimidine (compound 40 in Figure 7) was identified as a starting point for further investigation. It showed a good affinity for the $A_{2 A}$ receptor subtype and was 13 -fold more selective over $A_{1}$. The following introduction of 1-phenyl substitution (41) increased potency at $\mathrm{A}_{2 \mathrm{~A}}$ while either incorporation of heteroatoms or ring saturation did not improve affinity significantly. Extension of spatial linker between the phenyl ring and pyrazole by more than one methylene group was found to provide an $\mathrm{hA}_{2 \mathrm{~A}}$ affinity profile similar to the 1-phenyl derivative. Furthermore, subsequent substitution on the meta-position of phenyl ring with electron-rich and deficient groups was tolerated, with the 3-chlorobenzyl derivative (42) demonstrating the best $\mathrm{hA}_{2 \mathrm{~A}}$ affinity and selectivity in the series. Moreover, compounds 40-42 have also shown in vivo activity in a mouse haloperidol-induced hypolocomotion model of Parkinson's disease. Due to the fact that the 4-(furan-2-yl) moiety in this series of compounds could be easily converted into reactive species under oxidative metabolism, further studies were undertaken to replace such group with other nonfuran-containing heterocycles. Unfortunately, the resulting compounds have showed reduced affinity for the $\mathrm{A}_{2 \mathrm{~A}}$ receptor.

2.4.3. $A_{3}$ AR Antagonists. Pyrazolo-[3,4-d]pyrimidines represent a novel series of bicyclic scaffold-derived $A_{3}$ antagonists [46] isosterically related to the imidazole-[1,2a] $[1,3,5]$ triazine (43; Figure 8 ), which have shown a certain degree of binding affinity at both $A_{1}$ and $A_{3}$ receptors [56]. Such pyrazolo-pyrimidine analogues displayed improved $A_{3}$ affinity and selectivity profiles in comparison to the parent imidazole-triazines. From the binding affinity results, it was suggested that the 6-phenyl substituent at the bicyclic scaffold was a key pharmacophoric element for recognition at the ARs, since its removal led to poor affinity to all the ARs. Besides that, small alkyl groups at the $\mathrm{N}^{2}$-position, such as a methyl moiety were found to be more favourable than bulky groups for conferring good human $\mathrm{A}_{3}$ affinity. The introduction of $\mathrm{N}^{4}$-acyl substituents generally resulted in improved human $\mathrm{A}_{3}$ affinity relative to unsubstituted derivatives. In particular, the presence of a methyl group at $\mathrm{N}^{2}$, together with para-methoxy benzoyl substituent at $\mathrm{N}^{4}$ (44) dramatically increased the potency and selectivity to the $\mathrm{A}_{3} \mathrm{AR}$. Compound 44 was subsequently tested on human glioma U87MG cells, and it was able to counteract the proliferation of glioma cells mediated by $\mathrm{A}_{3}$ AR agonists Cl-IB-MECA and IBMECA through the inhibition of $\mathrm{A}_{3}$ AR agonist-mediated ERK $1 / 2$ activation. This finding implied that this class of derivatives might represent promising lead compounds for the development of adjuvants for glioma chemotherapy [46]. 
<smiles>CC(Sc1nc(SC(C)C(N)=O)c2cnn(-c3ccccc3)c2n1)C(N)=O</smiles>

37<smiles>CCCCC(Sc1nc(N)c2cnn(-c3ccccc3)c2n1)C(N)=O</smiles>

38<smiles>CCCCC(Sc1nc(NC)c2cnn(-c3ccccc3)c2n1)C(N)=O</smiles>

39

Figure 6: Structures of pyrazolo- $[3,4-d]$ pyrimidines as $A_{1}$ AR antagonists.<smiles>Nc1nc(-c2ccco2)c2cn[nH]c2n1</smiles>

40<smiles>Nc1nc(-c2ccco2)c2cnn(-c3ccccc3)c2n1</smiles>

41<smiles>Nc1nc(-c2ccco2)c2cnn(-c3cccc(Cl)c3)c2n1</smiles>

42

FIgURE 7: Structures of pyrazolo-[3,4-d]pyrimidines as $\mathrm{A}_{2 \mathrm{~A}} \mathrm{AR}$ antagonists.

\subsection{Pyrazolo-[1,5-a]pyridines}

2.5.1. $A_{1}$ AR Antagonists. Akahane and coworkers reported a series of pyrazolo-[1,5-a]pyridine derivatives as potent and selective $A_{1}$ AR antagonists. FK453 (45 in Figure 9) [47] and FK838 (46) [48] were the typical examples of such derivatives, and they also showed diuretic activity both in vivo and in vitro. Nevertheless, there were some limitations in these two compounds. For FK453, photochemical transcis isomerization at the acryloyl amide moiety and low water solubility $(11.9 \mu \mathrm{g} / \mathrm{mL})$ were two main problems in this type of structure. In FK838, photochemical stability was achieved through the substitution of the acryloyl amide with a pyridazinone ring while water solubility $(10 \mathrm{mg} / \mathrm{mL}$ ) was enhanced by the introduction of the butyric acid group. Nevertheless, this derivative had lower binding affinity and poorer selectivity for $A_{1}$ receptor than FK453. Subsequently, further structural modifications to FK838 led to the synthesis of FR166124 (47) [49], which is the most potent and selective $A_{1} A R$ antagonist of this series, and it shows high water solubility $(>200 \mathrm{mg} / \mathrm{mL})$. In fact, it was designed based on the hypothesis that the high affinity and selectivity of FK453 for the $A_{1}$ receptor was due to the presence of the (2R)-2-(2-hydroxyethyl)piperidine ring of 
<smiles>Cc1cn2c(NC(=O)c3ccccc3)nc(-c3ccccc3)nc2n1</smiles>

43<smiles>COc1ccc(C(=O)Nc2nc(-c3ccccc3)nc3nn(C)cc23)cc1</smiles>

44

Figure 8: Structures of (a) parent scaffold, imidazole[1,2-a][1,3,5]triazine as an $\mathrm{A}_{1}$ and $\mathrm{A}_{3} \mathrm{AR}$ antagonist; (b) pyrazolo-[3,4- $\left.d\right]$ pyrimidine as an $\mathrm{A}_{3} \mathrm{AR}$ antagonist.

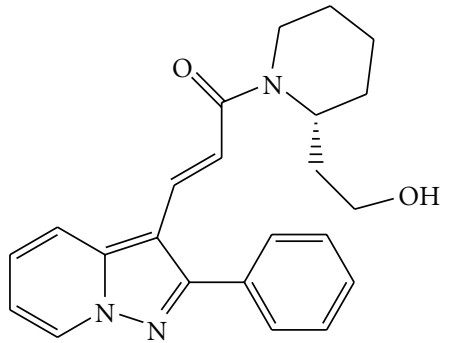

45

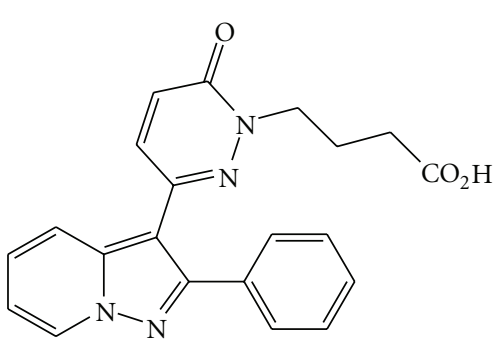

46<smiles>O=C(O)CC1=C(n2nc(-c3c(-c4ccccc4)nn4ccccc34)ccc2=O)CCCC1</smiles>

47

FIGURE 9: Structures of pyrazolo-[1,5-a]pyridine as $\mathrm{A}_{1} \mathrm{AR}$ antagonists.

the acryloyl amide as a conformationally limiting factor. The pyridazinone ring of FK838 was maintained in the structure of FR166124, with the introduction of a ring structure joining the $\mathrm{C}^{3}$ and $\mathrm{C}^{4}$ positions of the butyric acid group to limit possible conformations. Overall, the close resemblance of X-ray crystal structures of FR166124 and FK453 to each other, together with the experimental binding assay data, suggested that the presence of a double bond in the cyclohexenyl acetic acid group was essential for high selectivity to the $A_{1}$ receptor, with good $A_{1}$ affinity and water solubility.

\section{Conclusion}

Pyrazolo-containing polyheterocyclic scaffolds have given rise to a group of potent and selective antagonists for the $A_{1}$, $A_{2 A}, A_{2 B}$, and $A_{3} A R$ subtypes. An overview of the structureactivity relationships of each class of derivatives not only clarifies the structural requirements deemed essential for the affinity towards the individual AR subtypes, but it also lends insight into the rational design and optimization of existing structural templates to obtain other new, potent AR antagonists.

\section{Abbreviations}

$\operatorname{AR}(\mathrm{s}): \quad$ adenosine receptor(s)

cAMP: cyclic adenosine monophosphate

Cl-IB- 2-chloro- $\mathrm{N}^{6}$-(3-iodobenzyl)-5' $-\mathrm{N}$-methylcar-

MECA: boxamidoadenosine

ERK 1/2: extracellular signal-regulated kinase

8FB-PTP: 5-amino-8-(4-fluorobenzyl)-2-(2-furyl)-pyrazolo[4,3-e]-1,2,4-triazolo[1,5-c]pyrimidine

FK453: 2-phenylpyrazolo[1,5-a]pyridine-3-((2R)-2-(2hydroxyethyl)piperidyl)acryloylamides

FK838: 3-(2-butyric acid-3-oxo-2,3-dihydropyridazin6-yl)-2-phenylpyrazolo[ $[1,5-a]$ pyridine

FR166124: 3-(2-cyclohexenyl acetic acid-3-oxo-2,3-dihydropyridazin-6-yl)-2phenylpyrazolo[1,5-a]pyridine

GPCR: $\quad$ G protein-coupled receptor

$\left[{ }^{3} \mathrm{H}\right]$ MRE- $\left[{ }^{3} \mathrm{H}\right]-5-\mathrm{N}-(4-m e t h o x y p h e n y l c a r b a m o y l) a m i n o-$

3008-F20: 8-propyl-2-(2-furyl)pyrazolo[4,3-e]-1,2,4-triazolo[ $[1,5-c]$ pyrimidine

IB-MECA: $\mathrm{N}^{6}$-(3-iodobenzyl)-5' - N-methylcarboxamidoadenosine 
MAPK: $\quad$ mitogen-activated protein kinase

MRS5346: 5-((2-(2-(4-(3-(5-amino-2-(furan-2-yl)-7Hpyrazolo[4,3-e][1,2,4] triazolo[1,5-c]pyrimidin-7-yl)propyl)phenoxy)acetamido)ethyl)carbamoyl)-2-(6-amino-3-iminio-4,5-disulfonato-3H-xanthen-9-yl)benzoate

NECA: N-ethylcarboxamidoadenosine PET: $\quad$ positron emission tomography

SCH 63390: 5-amino-7-(3-phenyl propyl)-2-(2-furyl)pyrazolo[4,3-e]1,2,4-triazolo[1,5-c]pyrimidine

SCH 58261: 5-amino-7-( $\beta$-phenylethyl)-2-(2-furyl)pyrazolo[4,3-e]1,2,4-triazolo[1,5-c]pyrimidine

SCH 442416: 5-amino-7-[3-(4-methoxyphenyl)propyl]-2(2-furyl)pyrazolo[4,3-e]-1,2,4-triazolo[1,5c]pyrimidine

SCH 420814: 5-amino-7-[(2-(4-methoxyethoxyphenyl)piperazin-1-yl] ethyl-2-(2-furyl)-pyrazolo [4,3-e]1,2,4-triazolo[1,5-c]pyrimidine.

\section{Acknowledgments}

This paper was supported by the National Medical Research Council, Singapore (Grant no. NMRC/NIG/0020/2008) and the National University of Singapore (FRC Grant no. R-148000-129-112).

\section{References}

[1] K. A. Jacobson and Z. G. Gao, "Adenosine receptors as therapeutic targets," Nature Reviews Drug Discovery, vol. 5, no. 3, pp. 247-264, 2006.

[2] S. Moro, Z. G. Gao, K. A. Jacobson, and G. Spalluto, "Progress in the pursuit of therapeutic adenosine receptor antagonists," Medicinal Research Reviews, vol. 26, no. 2, pp. 131-159, 2006.

[3] W. J. Welch, "Adenosine $A_{1}$ receptor antagonists in the kidney: effects in fluid-retaining disorders," Current Opinion in Pharmacology, vol. 2, no. 2, pp. 165-170, 2002.

[4] T. V. Dunwiddie and S. A. Masino, "The role and regulation of adenosine in the central nervous system," Annual Review of Neuroscience, vol. 24, pp. 31-55, 2001.

[5] K. A. Jacobson, "Adenosine $A_{3}$ receptors: novel ligands and paradoxical effects," Trends in Pharmacological Sciences, vol. 19, no. 5, pp. 184-191, 1998.

[6] T. Okamura, Y. Kurogi, K. Hashimoto, H. Nishikawa, and Y. Nagao, "Facile synthesis of fused 1,2,4-triazolo[1,5c]pyrimidine derivatives as human adenosine $\mathrm{A}_{3}$ receptor ligands," Bioorganic and Medicinal Chemistry Letters, vol. 14, no. 10, pp. 2443-2446, 2004.

[7] S. Merighi, P. Mirandola, K. Varani et al., "Pyrazolotriazolopyrimidine derivatives sensitize melanoma cells to the chemotherapic drugs: taxol and vindesine," Biochemical Pharmacology, vol. 66, no. 5, pp. 739-748, 2003.

[8] R. Grondin, P. J. Bédard, A. H. Tahar, L. Grégoire, A. Mori, and H. Kase, "Antiparkinsonian effect of a new selective adenosine $\mathrm{A}_{2 \mathrm{~A}}$ receptor antagonist in MPTP-treated monkeys," Neurology, vol. 52, no. 8, pp. 1673-1677, 1999.

[9] P. Jenner, "Istradefylline, a novel adenosine $A_{2 A}$ receptor antagonist, for the treatment of Parkinson's disease," Expert Opinion on Investigational Drugs, vol. 14, no. 6, pp. 729-738, 2005.
[10] I. Feoktistov, I. Biaggioni, R. Polosa, and S. T. Holgate, "Adenosine $A_{2 B}$ receptors: a novel therapeutic target in asthma?" Trends in Pharmacological Sciences, vol. 19, no. 4, pp. 148-153, 1998.

[11] S. T. Holgate, "The identification of the adenosine $A_{2 B}$ receptor as a novel therapeutic target in asthma," British Journal of Pharmacology, vol. 145, no. 8, pp. 1009-1015, 2005.

[12] S. Schenone, M. Radi, and M. Botta, "Pyazolopyrimidines: old molecules, new targets," Targets in Heterocyclic SystemsChemistry and Properties, vol. 11, pp. 44-69, 2007.

[13] F. Gatta, M. R. Del Giudice, A. Borioni, P. A. Borea, S. Dionisotti, and E. Ongini, "Synthesis of imidazo[1,2c]pyrazolo[4,3-e]pyrimidines, $\quad$ pyrazolo[4,3-e]1,2,4triazolo[1,5-c]pyrimidines and 1,2,4-triazolo[5,1-i]purines: new potent adenosine $\mathrm{A}_{2}$ receptor antagonists," European Journal of Medicinal Chemistry, vol. 28, no. 7-8, pp. 569-576, 1993.

[14] P. G. Baraldi, S. Manfredini, D. Simoni et al., "Sythesis of new pyrazolo[4,3-e]1,2,4-triazolo[1,5-c] pyrimidine and 1,2,3-triazolo[4,5-e]1,2,4-triazolo[1,5-c] pyrimidine displaying potent and selective activity as $\mathrm{A}_{2 \mathrm{~A}}$ adenosine receptor antagonists," Bioorganic and Medicinal Chemistry Letters, vol. 4, no. 21, pp. 2539-2544, 1994.

[15] P. G. Baraldi, B. Cacciari, G. Spalluto et al., "Pyrazolo[4,3-e]1,2,4-triazolo[1,5-c]pyrimidine derivatives: potent and selective $\mathrm{A}_{2 \mathrm{~A}}$ adenosine antagonists," Journal of Medicinal Chemistry, vol. 39, no. 5, pp. 1164-1171, 1996.

[16] P. G. Baraldi, B. Cacciari, G. Spalluto et al., "Design, synthesis, and biological evaluation of a second generation of pyrazolo[4,3-e]-1,2,4-triazolo[1,5-c]pyrimidines as potent and selective $\mathrm{A}_{2 \mathrm{~A}}$ adenosine receptor antagonists," Journal of Medicinal Chemistry, vol. 41, no. 12, pp. 2126-2133, 1998.

[17] P. G. Baraldi, B. Cacciari, R. Romagnoli et al., "7-substituted 5-amino-2-(2-furyl)pyrazolo[4,3-e]-1,2,4-triazolo[1,5-

c]pyrimidines as $\mathrm{A}_{2 \mathrm{~A}}$ adenosine receptor antagonists: a study on the importance of modifications at the side chain on the activity and solubility," Journal of Medicinal Chemistry, vol. 45, no. 1, pp. 115-126, 2002.

[18] S. Dionisotti, S. Ferrara, C. Molta, C. Zocchi, and E. Ongini, "Labeling of $\mathrm{A}_{2 \mathrm{~A}}$ adenosine receptors in human platelets by use of the new nonxanthine antagonist radioligand [ $\left.{ }^{3} \mathrm{H}\right] \mathrm{SCH}$ 58261," Journal of Pharmacology and Experimental Therapeutics, vol. 278, no. 3, pp. 1209-1214, 1996.

[19] S. Todde, R. M. Moresco, P. Simonelli et al., "Design, radiosynthesis, and biodistribution of a new potent and selective ligand for in vivo imaging of the adenosine $A_{2 A}$ receptor system using positron emission tomography," Journal of Medicinal Chemistry, vol. 43, no. 23, pp. 4359-4362, 2000.

[20] M. Kecskés, T. S. Kumar, L. Yoo, Z. G. Gao, and K. A. Jacobson, "Novel Alexa Fluor-488 labeled antagonist of the $\mathrm{A}_{2 \mathrm{~A}}$ adenosine receptor: application to a fluorescence polarization-based receptor binding assay," Biochemical Pharmacology, vol. 80, no. 4, pp. 506-511, 2010.

[21] P. G. Baraldi, B. Cacciari, R. Romagnoli et al., "Pyrazolo[4,3e]-1,2,4-triazolo[1,5-c]pyrimidine derivatives as highly potent and selective human $\mathrm{A}_{3}$ adenosine receptor antagonists," Journal of Medicinal Chemistry, vol. 42, no. 22, pp. 4473-4478, 1999.

[22] P. G. Baraldi, B. Cacciari, R. Romagnoli et al., "Pyrazolo[4,3e] 1,2,4-triazolo[1,5-c]pyrimidine derivatives as highly potent and selective human $\mathrm{A}_{3}$ adenosine receptor antagonists: influence of the chain at the $\mathrm{N}^{8}$ pyrazole nitrogen," Journal of Medicinal Chemistry, vol. 43, no. 25, pp. 4768-4780, 2000. 
[23] B. R. Neustadt, J. Hao, N. Lindo et al., "Potent, selective, and orally active adenosine $\mathrm{A}_{2 \mathrm{~A}}$ receptor antagonists: arylpiperazine derivatives of pyrazolo[4,3-e]-1,2,4-triazolo[1,5c]pyrimidines," Bioorganic and Medicinal Chemistry Letters, vol. 17, no. 5, pp. 1376-1380, 2007.

[24] P. G. Baraldi, B. Cacciari, R. Romagnoli et al., "Pyrazolo[4,3e] 1,2,4-triazolo[1,5-c]pyrimidine derivatives as adenosine receptor ligands: a starting point for searching $\mathrm{A}_{2 \mathrm{~B}}$ adenosine receptor antagonists," Drug Development Research, vol. 53, no. 2-3, pp. 225-235, 2001.

[25] G. Pastorin, T. Da Ros, G. Spalluto et al., "Pyrazolo[4,3e]-1,2,4-triazolo[1,5-c]pyrimidine derivatives as adenosine receptor antagonists. Influence of the $\mathrm{N}^{5}$ substituent on the affinity at the human $\mathrm{A}_{3}$ and $\mathrm{A}_{2 \mathrm{~B}}$ adenosine receptor subtypes: a molecular modeling investigation," Journal of Medicinal Chemistry, vol. 46, no. 20, pp. 4287-4296, 2003.

[26] K. Varani, S. Merighi, S. Gessi et al., "[ $\left.{ }^{3} \mathrm{H}\right]$ MRE 3008F20: a novel antagonist radioligand for the pharmacological and biochemical characterization of human $\mathrm{A}_{3}$ adenosine receptors," Molecular Pharmacology, vol. 57, no. 5, pp. 968-975, 2000.

[27] P. G. Baraldi, B. Cacciari, S. Moro et al., "Synthesis, biological activity, and molecular modeling investigation of new pyrazolo[4,3-e]-1,2,4-triazolo[1,5-c]pyrimidine derivatives as human $\mathrm{A}_{3}$ adenosine receptor antagonists," Journal of Medicinal Chemistry, vol. 45, no. 4, pp. 770-780, 2002.

[28] G. Pastorin, T. Da Ros, C. Bolcato et al., "Synthesis and biological studies of a new series of 5-heteroarylcarbamoylaminopyrazolo[4,3-e]1,2,4-triazolo[1,5-c]pyrimidines as human $\mathrm{A}_{3}$ adenosine receptor antagonists. Influence of the heteroaryl substituent on binding affinity and molecular modeling investigations," Journal of Medicinal Chemistry, vol. 49, no. 5, pp. 1720-1729, 2006.

[29] S. Moro, P. Braiuca, F. Deflorian et al., "Combined targetbased and ligand-based drug design approach as a tool to define a novel 3D-pharmacophore model of human $\mathrm{A}_{3}$ adenosine receptor antagonists: pyrazolo[4,3-e $] 1,2,4$-triazolo[1,5c]pyrimidine derivatives as a key study," Journal of Medicinal Chemistry, vol. 48, no. 1, pp. 152-162, 2005.

[30] A. Maconi, G. Pastorin, T. Da Ros et al., "Synthesis, biological properties, and molecular modeling investigation of the first potent, selective, and water-soluble human $\mathrm{A}_{3}$ adenosine receptor antagonist," Journal of Medicinal Chemistry, vol. 45, no. 17, pp. 3579-3582, 2002.

[31] P. G. Baraldi, F. Fruttarolo, M. A. Tabrizi et al., "Design, synthesis, and biological evaluation of $\mathrm{C}^{9}$ - and $\mathrm{C}^{2}$-substituted pyrazolo[4,3-e]-1,2,4-triazolo[1,5-c]pyrimidines as new $\mathrm{A}_{2 \mathrm{~A}}$ and $A_{3}$ adenosine receptors antagonists," Journal of Medicinal Chemistry, vol. 46, no. 7, pp. 1229-1241, 2003.

[32] S. L. Cheong, A. Dolzhenko, S. Kachler et al., "The significance of 2-furyl ring substitution with a 2-(para-substituted) aryl group in a new series of pyrazolo-triazolo-pyrimidines as potent and highly selective $\mathrm{hA}_{3}$ adenosine receptors antagonists: new insights into structure-affinity relationship and receptor-antagonist recognition," Journal of Medicinal Chemistry, vol. 53, no. 8, pp. 3361-3375, 2010.

[33] T. Okamura, Y. Kurogi, K. Hashimoto et al., "Structureactivity relationships of adenosine $\mathrm{A}_{3}$ receptor ligands: new potential therapy for the treatment of glaucoma," Bioorganic and Medicinal Chemistry Letters, vol. 14, no. 14, pp. 37753779, 2004.

[34] V. Colotta, D. Catarzi, F. Varano et al., "1,2,4-triazolo[4,3a]quinoxalin-1-one: a versatile tool for the synthesis of potent and selective adenosine receptor antagonists," Journal of Medicinal Chemistry, vol. 43, no. 6, pp. 1158-1164, 2000.
[35] V. Colotta, D. Catarzi, F. Varano et al., "Synthesis and structure-activity relationships of a new set of 1,2,4-triazolo[4,3-a] quinoxalin-1-one derivatives as adenosine receptor antagonists," Bioorganic and Medicinal Chemistry, vol. 11, no. 16, pp. 3541-3550, 2003.

[36] V. Colotta, D. Catarzi, F. Varano et al., "1,2,4-triazolo[4,3a] quinoxalin-1-one moiety as an attractive scaffold to develop new potent and selective human $\mathrm{A}_{3}$ adenosine receptor antagonists: synthesis, pharmacological, and ligand-receptor modeling studies," Journal of Medicinal Chemistry, vol. 47, no. 14, pp. 3580-3590, 2004.

[37] O. Lenzi, V. Colotta, D. Catarzi et al., "4-amido-2-aryl-1,2,4triazolo[4,3-a]quinoxalin-1-ones as new potent and selective human $\mathrm{A}_{3}$ adenosine receptor antagonists. Synthesis, pharmacological evaluation, and ligand-receptor modeling studies," Journal of Medicinal Chemistry, vol. 49, no. 13, pp. 3916-3925, 2006.

[38] V. Colotta, D. Catarzi, F. Varano et al., "Synthesis, ligandreceptor modeling studies and pharmacological evaluation of novel 4-modified-2-aryl-1,2,4-triazolo[4,3-a] quinoxalin-1one derivatives as potent and selective human $\mathrm{A}_{3}$ adenosine receptor antagonists," Bioorganic and Medicinal Chemistry, vol. 16, no. 11, pp. 6086-6102, 2008.

[39] V. Colotta, D. Catarzi, F. Varano et al., "Synthesis and structure-activity relationships of a new set of 2-arylpyrazolo[3,4-c] quinoline derivatives as adenosine receptor antagonists," Journal of Medicinal Chemistry, vol. 43, no. 16, pp. 3118-3124, 2000.

[40] V. Colotta, D. Catarzi, F. Varano et al., "New 2-arylpyrazolo[3,4-c] quinoline derivatives as potent and selective human $\mathrm{A}_{3}$ adenosine receptor antagonists. Synthesis, pharmacological evaluation, and ligand-receptor modeling studies," Journal of Medicinal Chemistry, vol. 50, no. 17, pp. 4061-4074, 2007.

[41] P. G. Baraldi, M. A. Tabrizi, D. Preti et al., "New 2-arylpyrazolo[4,3-c] quinoline derivatives as potent and selective human $\mathrm{A}_{3}$ adenosine receptor antagonists," Journal of Medicinal Chemistry, vol. 48, no. 15, pp. 5001-5008, 2005.

[42] O. Lenzi, V. Colotta, D. Catarzi et al., "2-phenylpyrazolo[4,3d]pyrimidin-7-one as a new scaffold to obtain potent and selective human a adenosine receptor antagonists: new insights into the receptor-antagonist recognition," Journal of Medicinal Chemistry, vol. 52, no. 23, pp. 7640-7652, 2009.

[43] L. P. Davies, S. C. Chow, and J. H. Skerritt, "Pyrazolo[3,4d]pyrimidines as adenosine antagonists," Life Sciences, vol. 34, no. 22, pp. 2117-2128, 1984.

[44] S. A. Poulsen and R. J. Quinn, "Synthesis and structureactivity relationship of pyrazolo[3,4-d]pyrimidines: potent and selective adenosine $A_{1}$ receptor antagonists," Journal of Medicinal Chemistry, vol. 39, no. 21, pp. 4156-4161, 1996.

[45] R. J. Gillespie, I. A. Cliffe, C. E. Dawson et al., "Antagonists of the human adenosine $\mathrm{A}_{2 \mathrm{~A}}$ receptor. Part 3: design and synthesis of pyrazolo[3,4- $d]$ pyrimidines, pyrrolo[2,3d]pyrimidines and 6-arylpurines," Bioorganic and Medicinal Chemistry Letters, vol. 18, no. 9, pp. 2924-2929, 2008.

[46] S. Taliani, C. La Motta, L. Mugnaini et al., "Novel N Substituted pyrazolo[3,4-d]pyrimidine adenosine A receptor antagonists: inhibition of A-Mediated human glioblastoma cell proliferation," Journal of Medicinal Chemistry, vol. 53, no. 10, pp. 3954-3963, 2010.

[47] A. Akahane, H. Katayama, T. Mitsunaga et al., "Discovery of FK453, a novel non-xanthine adenosine $A_{1}$ receptor antagonist," Bioorganic and Medicinal Chemistry Letters, vol. 6, no. 17, pp. 2059-2062, 1996. 
[48] A. Akahane, H. Katayama, T. Mitsunaga et al., "Discovery of 6-oxo-3 (2-phenylpyrazolo[1,5-a]pyridin-3-yl) 1(6H)pyridazinebutanoic acid (FK 838): a novel non-xanthine adenosine $A_{1}$ receptor antagonist with potent diuretic activity," Journal of Medicinal Chemistry, vol. 42, no. 5, pp. 779-783, 1999.

[49] S. Kuroda, A. Akahane, H. Itani et al., "Discovery of FR166124, a novel water-soluble pyrazolo[1,5-a]pyridine adenosine $A_{1}$ receptor antagonist," Bioorganic and Medicinal Chemistry Letters, vol. 9, no. 14, pp. 1979-1984, 1999.

[50] B. B. Fredholm, K. Lindström, S. Dionisotti, and E. Ongini, " $\left[{ }^{3} \mathrm{H}\right] \mathrm{SCH} 58261$, a selective adenosine $\mathrm{A}_{2 \mathrm{~A}}$ receptor antagonist, is a useful ligand in autoradiographic studies," Journal of Neurochemistry, vol. 70, no. 3, pp. 1210-1216, 1998.

[51] M. El Yacoubi, C. Ledent, M. Parmentier, E. Ongini, J. Costentin, and J. M. Vaugeois, "In vivo labelling of the adenosine $\mathrm{A}_{2 \mathrm{~A}}$ receptor in mouse brain using the selective antagonist $\left[{ }^{3} \mathrm{H}\right] \mathrm{SCH} 58261, "$ European Journal of Neuroscience, vol. 14, no. 9, pp. 1567-1570, 2001.

[52] P. G. Baraldi, B. Cacciari, G. Spalluto et al., "Novel N ${ }^{6}$ (substituted-phenylcarbamoyl)adenosine- $5^{\prime}$-uronamides as potent agonists for $\mathrm{A}_{3}$ adenosine receptors," Journal of Medicinal Chemistry, vol. 39, no. 3, pp. 802-806, 1996.

[53] P. G. Baraldi, B. Cacciari, M. J. P. De Las Infantas et al., "Synthesis and biological activity of a new series of $\mathrm{N}^{6}$-arylcarbamoyl, 2-(Ar)alkynyl- $\mathrm{N}^{6}$-arylcarbamoyl, and $\mathrm{N}^{6}$ carboxamido derivatives of adenosine- $5^{\prime}-\mathrm{N}$-ethyluronamide as $\mathrm{A}_{1}$ and $\mathrm{A}_{3}$ adenosine receptor agonists," Journal of Medicinal Chemistry, vol. 41, no. 17, pp. 3174-3185, 1998.

[54] S. Gessi, K. Varani, S. Merighi et al., "Pharmacological and biochemical characterization of $\mathrm{A}_{3}$ adenosine receptors in Jurkat T cells," British Journal of Pharmacology, vol. 134, no. 1, pp. 116-126, 2001.

[55] S. Gessi, K. Varani, S. Merighi et al., " $\mathrm{A}_{3}$ adenosine receptors in human neutrophils and promyelocytic HL60 cells: a pharmacological and biochemical study," Molecular Pharmacology, vol. 61, no. 2, pp. 415-424, 2002.

[56] E. Novellino, E. Abignente, B. Cosimelli et al., "Design, synthesis and biological evaluation of novel N-alkyl- and Nacyl-(7-substituted-2-phenylimidazo[1,2-a][1,3,5] triazin-4yl)amines (ITAs) as novel $A_{1}$ adenosine receptor antagonists," Journal of Medicinal Chemistry, vol. 45, no. 23, pp. 5030-5036, 2002. 


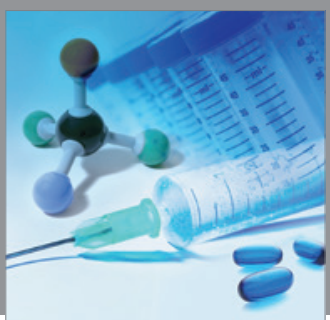

International Journal of

Medicinal Chemistry

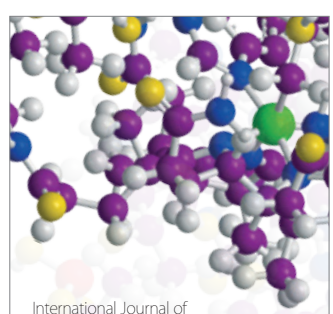

Carbohydrate Chemistry

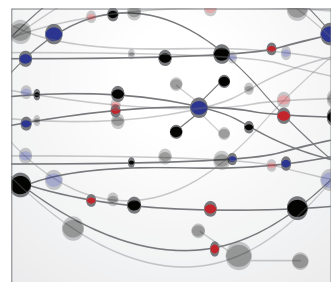

The Scientific World Journal
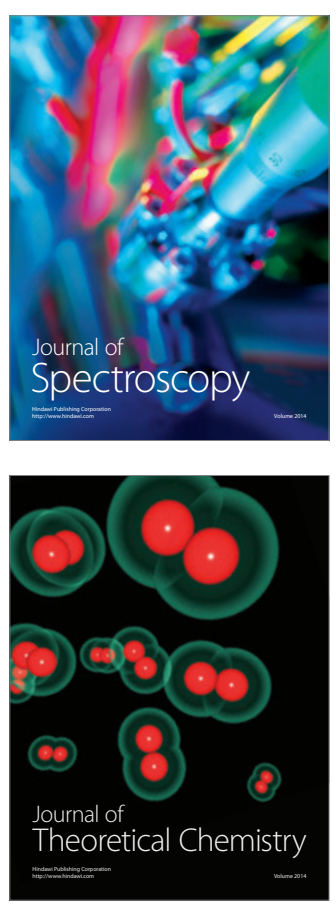
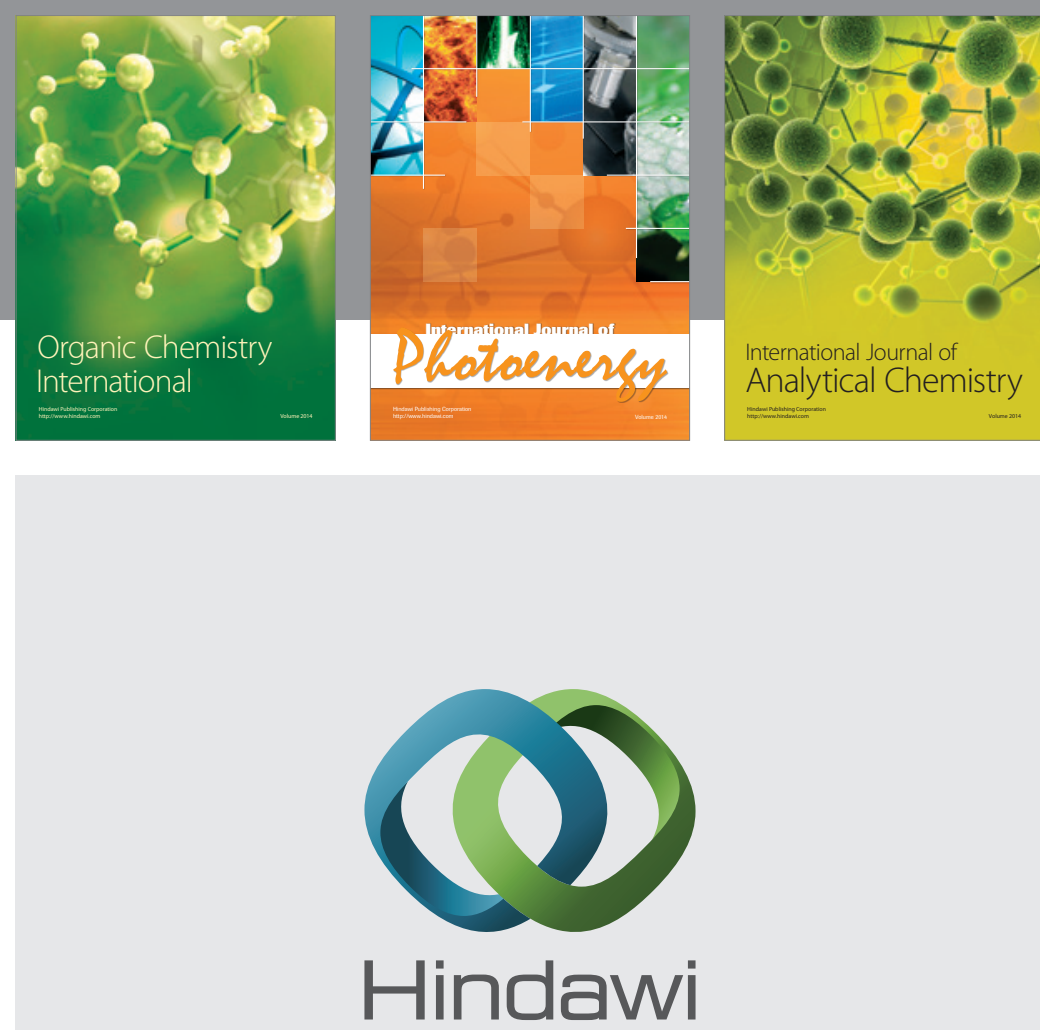

Submit your manuscripts at

http://www.hindawi.com
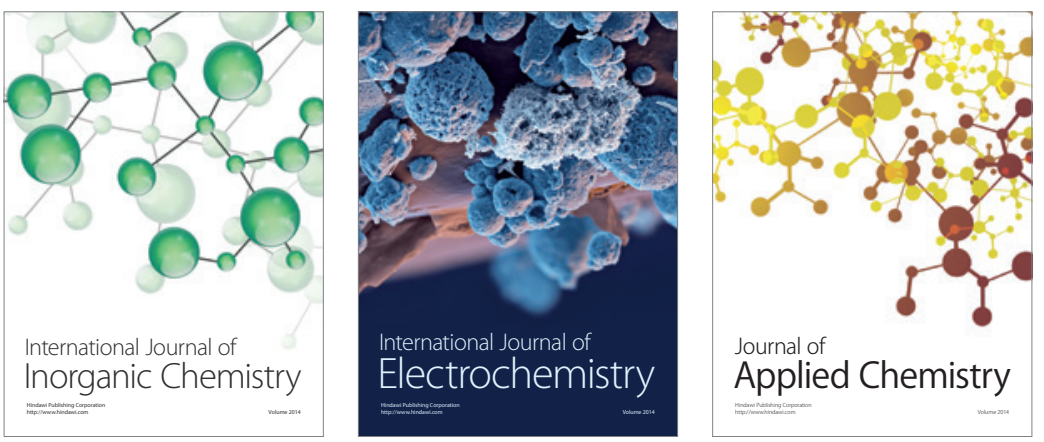

Journal of

Applied Chemistry
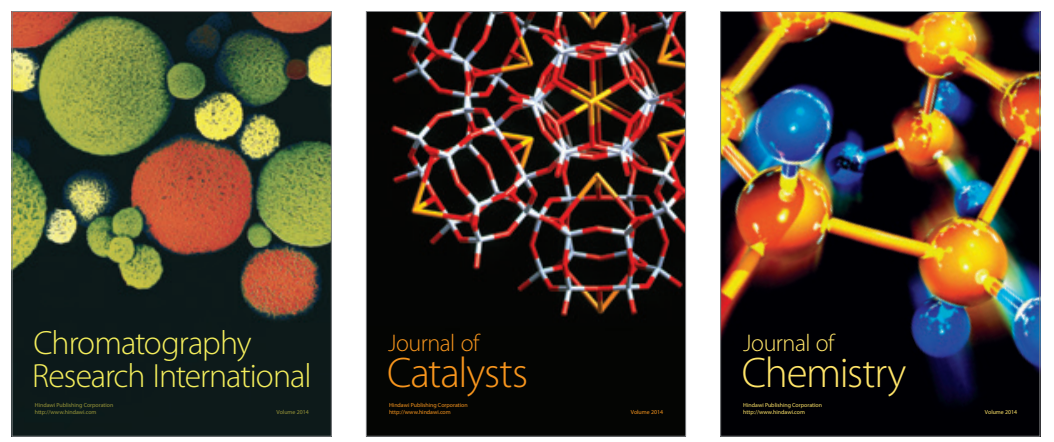
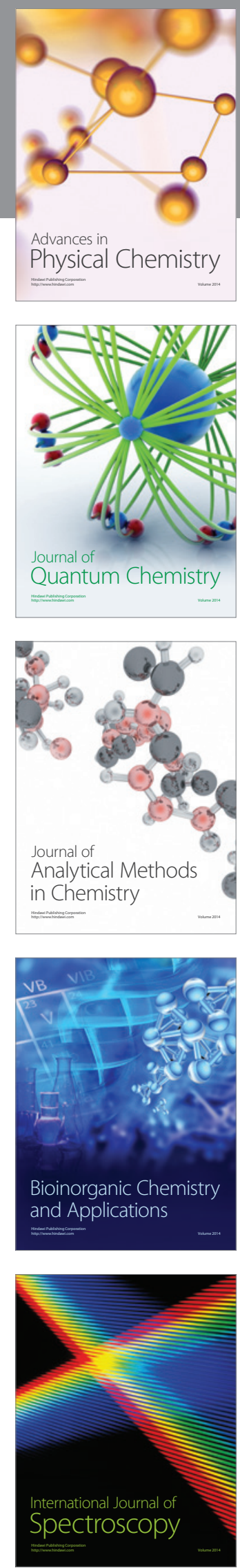